\title{
THE PARADOXES: POLITICS OF INEQUITY-POLICIES FOR HIGHER EDUCATION IN PAKISTAN
}

\author{
Dr. Sadruddin Bahadur Qutoshi \\ Assistant Professor, Karakorum International University, Gilgit-Baltistan, Pakistan \\ Email: sadruddin.qutoshi@kiu.edu.pk \\ Dr. Zahra Jabeen \\ Lecturer, Karakorum International University, Gilgit-Baltistan, Pakistan \\ Email: zahra.jabeen@kiu.edu.pk
}

\author{
Dr. Dil Angaiz \\ Assistant Professor, Department of Educational Development, Karakoram International \\ University, Gilgit-Baltistan \\ Email: dilangaiz@kiu.edu.pk
}

\begin{abstract}
This reflective paper aims to explore in what ways equity-based empowering educational policies can reduce disparities of marginalized people' access to opportunities for quality higher education in Pakistan; and how the 'topocracy' in Pakistan clutches education policies for their own interest. Using the critical reflective lens, the authors engage with reflections on secondary data on education policies (1947-2009) and policy analysis papers to make meaning. Making meaning is a critical reflective engagement and an approach to data analysis that enables the researchers to draw meanings of complex socio-political and educational phenomena. It enables researchers to present the key findings on ground practices based on current higher education policies of Pakistan. The findings show that policies developed on equality basis could not help the marginalized segments in Pakistan with regard to access to quality higher education. It appears that the inequity-policies and practices created a huge gap between haves and have-nots fostering disparities, sense of isolation and deprivation among the marginalized people who have no access to quality higher education such as Gilgit-Baltistan, Chitral, Baluchistan, South Punjab, interior Sindh and other border areas of Pakistan. This study recommends policymakers to reflect on what ways bringing reforms to the existing policies to introduce opportunities for equity -friendly-polices for the marginalized areas to reduce their sense of deprivation.
\end{abstract}

Keywords: Inequity-Policies, Support Provisions, Higher Education, Marginalized Areas Quality-lifebasics, Topocracy

\section{INTRODUCTION}

Generally, education in Pakistan has been a least prioritized sector that could not receive its due attention towards devising policies in line with equity based rather than an equality focused access to and quality of education to everyone in the age of formal schooling including students living in marginalized segments of society (Ali, 2006, 2009, 2012, 2013). History shows that despite emphasis by donor agencies, international organizations and researchers very less is done to address issues related to poor allocation of education budget, internal and external influence, (Ali \& Tahir, 2009) absence of equity focused policies and mismanagement of resources in education to name but a few. Moreover, factors such as influence of a typical class of people in the policy making led the country to "respond more to the globalization process rather than national needs" (Ali, 2017, 2005). This shows that education policies of Pakistan are silent on equity centered policies, which are in the interest of marginalized areas of the country, in order to improve its access to and quality of education in general and higher education in particular.

The study of education policies of the country especially the higher education, enabled the researchers to infer that Pakistan has been under the influence of a particular ruling class such as feudal lords, military and civil services higher ups with their own mindset and interests that has been part and parcel of many forms of governance and government in the country from time to time. Whatever the form of governance and government has been so far, unfortunately, could not address the real issues of access to and quality of higher education to everyone especially the people from marginalized areas of Pakistan. 
Resultantly, the marginalized class remained unable to have access to quality higher education for generations.

It would not be wrong to call the ruling class in Pakistan topocrates ${ }^{4}$ and the practice of their influence as topocracy. This class holds powers at the top level and rules the country since 1947 with a lowest interest of education for the people that Jürgen Habermas (2015) calls a technical interest of education. It is an education which aims to develop masses as obedient learners rather than critically reflective thinkers. Thus, providing an education on these lines in Pakistan enabled the topocracy to create masses as obedient and blind flowers. Interestingly, one of the examples of such kind of masses, the blind followers can be seen during election campaigns, TV shows, debates of political leaders, so called intellectuals etc.

Probably, creating such a mindset of voters, one definitely needs a very traditional, narrowly conceived view of education that could generate so-called educated masses who cannot even question themselves, their own notions, and their leaders. On the other hand, for the ruling class there are institutions which offer another brand of education, probably a practical interest of education (Habermas, 2015) - an education with more freedom to knowledge generation and skills with an attitude to lead others that is unfortunately inaccessible to general masses of this country. This could be a meaningcentered education that has the power to think critically and make a decision based on what is right or wrong that makes sense to live respectable ways of living. Thus, over 74 years of life this country could not decide its direction towards an empowering view of education for all including marginalized segments of societies in the country and provide more opportunities to less developed, deprived and poor segments of societies through equity centered policies. This historical blunder of policy makers created multiple brands of education and their practices created multiple layers of classes in the country which highly demand equity-based policies to bring all of them to a certain level of educational standards based on an emancipatory interest of education.

These multiple brands of education and a diverse range of quality standards are the result of the absence of equity-based policies, plans, and practices in Pakistan, which need to be addressed to provide an education that is of international standards where everyone should get opportunities according to their capacity. The existing policies and practices are highly linked with the mindset and or the unconscious attitude of new colonial masters, the topocrates, making poor people poorer and rich ones the richer. Reflections show that this influential class has hijacked the system of governance since the inception of Pakistan (1947). This class has never been in favor of improving every affair of the 'lifeworld' of people especially the marginalized ones including their access to higher education. However, the notion of a 'single curriculum for the nation' could be the first step to think about the direction of education but how to reach at the destination, equity-centered policies will play their role to a greater extent that seem missing in the context.

Here the purpose of coining the term 'topocracy'- a new form of colonization in the hands of this influential class, and critiquing on this class is manifold. As this class represents a highly influential group of people who ruled the country during post-colonization created many disparities among masses. To understand the mindset of this class and its influence on poor segments of society, the academia in Pakistan and beyond need to focus on the problems and issues of inequity policies within its contextual settings. In doing so, it will create awareness among the masses and enable them to raise their voices against such injustices. Secondly, it will create an opportunity for the said class to reflect on their thinking and behavior in order to ensure a meaning-centered education to every citizen of this country.

\section{METHODOLOGICAL POSITIONING}

In the light of the above discussion on the problems and issues of inequity-based disempowering policies, the researchers came to realize that a "critical social research" (Carspecken, 1996, p.18) under critical paradigm appears to be one of the best approaches to conduct this research. The researchers focused on a critical discourse analysis with the critical reflective lens as a methodological approach to research (Fairclough, 2013). Thus, to address such chronic issues and problems related to policy and practices influenced by a particular class (i.e., a socio-political mindset), critical research perspective creates space for the researchers to understand phenomena at a deeper level. Within this domain, research as a critical theory perspective employs critically reflective lenses that appear to be one of the most feasible tools of research in such cases. 
Critical theory perspective enables the researchers as knowers not only to inform self and others but also to critique and take actions for self and others about the beliefs, perceptions, and practices of people living under such conditions. Moreover, research from a critical theory perspective creates conditions for the researchers to not only reflect on issues critically rather than suggests contextual solutions and takes appropriate actions at their own level to bring improvements in the existing conditions. Making meaning is a critical reflective engagement and an approach to data analysis that enables the researchers to draw meanings of complex socio-political and educational phenomena (Fairclough, 2013).

Employing a critically reflective approach as a method of inquiry (Brookfield, 1995) the researchers came up with key findings which explain the contextual biased picture (Carspecken, 1996) of the overall scenario of the country's inequity policies of higher education. Probably, the following findings will help the readership to make better sense of the existing situation of education in Pakistan and reflect on self and others to address in what ways they could be affected due to such kind of educational policies and practices, and what corrective actions will be taken in future to help the new generation.

\section{RESULTS AND DISCUSSIONS \\ Outcomes of Multiple Brand of Education under Topocracy}

In this shrinking globe, the opportunities for access to quality higher education on equity rather than equality basis depends on a fair consideration of socioeconomic, geographic, religious status, and structures of societies etc. (Khan, 2011) to provide better life chances to masses. However, the absence of such equity-based policies "In Pakistan "... the higher education system fares no better, in spite of strides made in the past decade. Enrolment stands at about $8 \%$...of the age cohort, with countries such as India at $18 \%$ and Malaysia at $42 \%$..." (Aziz et al., 2014, p.4). Looking at the overall situation of higher education in a polarized society of Pakistan the question of providing access to quality higher education on an equity basis appears to be discouraging.

There are two major interests of education in Pakistan; one is an education with empowering views (that is only available to few ruling classes and/or financially well off families) as compared to education with a narrowly conceived view could hardly create learners as obedient blind followers. Such multiple interests in education have been one of the factors affecting access to quality higher education in Pakistan. Studies showed that the Islamic Republic of Pakistan ranks second lowest after Afghanistan as 1.5 percent participation in higher education among its neighbors in terms of both quantity due to lack of access to and quality of graduates in higher education (Mehmood, 2016; Qutoshi, 2015). The situation is more serious with reference to graduates belonging to underdeveloped areas particularly those bordered areas such as Gilgit-Baltistan. For example, having no constitutional rights as first-class citizens (to raise their voice in policy making chambers and to cast vote for the selection of Priminister), limited opportunities to governance and administrative positions, and lack of quality health and educational facilities, contribute towards developing a sense of deprivation among graduates.

The position of the country in terms of quality higher education becomes weaker when we compare it with other progressive countries of Asia like Maldives, Malaysia, and Singapore and beyond (Aziz et al, 2014). However, since 1947 the Government of Pakistan (GoP) has not been able to address the key issues of access to quality higher education (Muzaffar, 2010) due to a political-donor-driven agenda that can only facilitate new colonial masters. As a result, none of the efforts with such policies could help the general masses to get quality higher education easily to develop the country in a real sense. Pakistan came into being after the demise of the Colonization with big ' $\mathrm{C}$ ' giving birth to a new form of colonization-topocracy, with small ' $c$ ' that unfortunately did not seriously consider even to define the term equity.

This study also attempts to highlight the importance of equity to define clearly at policy level so as to enable the implementers to provide equity-centered support. It was found that the term equity has not even been defined in any policy with clarity. The new colonial masters created more space for themselves and their beneficiaries based on equality for all rather than facilitating the masses/graduates belonging to highly disadvantageous regions of the country especially Gilgit-Baltistan $(G B)$. Thus, for topocracy introducing equity-based effective policies which would enable lower segments of society appears to be less desirable. Mehmood (2016) in his report on 'Overall assessment of higher education sector' assessed overall situation of higher education in Pakistan recommended to introduce policies on 
equity basis to increase access to higher education that would help people of unprivileged regions of Pakistan. In doing so, people belonging to disadvantageous areas can get relief and it could reduce their sense of deprivation.

However, history of Pakistan showed that topocracy is the class that holds power at the center and rules the country in one or the other forms of governance since 1947. The class, for example, Elitismincluding political gamers and jammers and bureaucratic giants, Lordism, Vadarism, Khanism, Nawabism, Mirism (Qutoshi, 2015) and Generalism, to name but a few, that is ruling the masses in Pakistan since its inception. Resultantly, the masses in one or the other forms suffered and are constantly suffering due to the formation of self-centered policies by this class. Thus, the researchers argued that the existing policies are ineffective to improve the state of higher education of the people in general and that of marginalized ones in particular (Morley, 1997) rather more friendly towards upper economic class and the topocracy.

\section{Complex Issues of Marginalization: A Historical Perspective}

In Pakistan, the policies on access to and quality of 'equity-directed activities' (Ramsay, 1999, p.3), and the practices on the ground have been silent since its inception (Qutoshi, 2015). With regard to education and the type of education we chose for the new generation that can define the future of Pakistan was though discussed by the father of the nation, Muhammad Ali Jinnah in his inaugural address of the very first education conference in 1947. He said, “...there is no doubt that the future of our State will and must greatly depend upon the type of education we give to our children and the way in which we bring them up as future citizens of Pakistan". The question is how seriously this notion was taken into consideration while devising educational policies and implementing them on the grass root level.

In fact, the notion of Jinnah's speech though highlighted the importance of education to some extent but the implementation part of how to do it seemed missing in almost all educational policies. Looking at Hoodbhoy's reflection on this speech shows that Mohammed Ali Jinnah, the founder of Pakistan, did not consider educational and scientific development as a top priority similar to Jawaharlal Nehru of India (Hoodbhoy, n.d). The outcome of the educational politics in Pakistan can be seen in the form of many disparities among different geographical and ethnic divides within and beyond the provinces. Resultantly, it created multiple layers of the state of education in general and higher education in particular in the country with huge gaps between rural versus urban and male versus female, one province versus another province, to name but a few (Malik \& Courtney, 2011).

Reflections revealed that, unfortunately, the above guidance of the father of nation lost its essence due to an unclear direction and precise plan on one hand and on the other hand the politics of the ruling class, who took it the other way round rather taking it seriously for the betterment of general masses. However, many false promises were made to improve access to education and targets were fixed for twenty years (1947-1967) but none of such successive policies could address the issues of equity in education and were failed to give the desirable results.

The issues of equity in education and gender parity and strategies to resolve such issues were not even taken seriously in the first educational conference followed by other successive policies later on. Instead of having a diverse range of disparity issues embedded in the heritage of a state that came into its existence after colonial disintegration, no serious efforts were made to develop all citizens of the country depending on their rights and privileges.

In addition to keeping education below 'top priority' agenda, the issues of poor policy formulation, lack of interest in implementation and nonexistence of effective monitoring and evaluation mechanisms in the system of governance in the country cannot be ignored. Till National Education Policy of GoP (2009) the new colonial masters could not put the country on the path of real progress with a quality education at all levels that was promised (Ramsay, 1999). However, from time to time on contingency basis GoP has been reforming its' policies and plans, for example, NEP/conference 1947, the Report on the Commission on National Education 1959, NEP 1970, 72, 79, 92, 98-2010, 2001-2006, NEP 2009 to NEP 2017- so far the latest one to improve state of access to and quality of education at all levels (Khushik \& Diemer, 2018; Qutoshi, 2015). Moreover, the outcomes of these successive policies have been frustrating and ineffective due to many reasons such as the absence of political will, lack of commitment, the absence of review and critical reflections on policies and practices, and lack of honesty in discharging the responsibilities as responsible citizens of Pakistan at all levels. 
For example, one of the history long existing issues of disparity of many kinds was first highlighted by the report of the Commission on National Education (1959) that both boys and girls should be given equal opportunities to get education. It should be very clear that Pakistan' more than 50\% population is female and the policies till 1959 have been silent on this important issue regardless of this reality. This reflects clearly that to what extent the policy makers, planners, and administrators are insensitive to the collective development of masses.

Similarly, the same issue was taken again in NEP (1979), after twenty years, because no significant development was seen as a result of the previous policies. In NEP 1979, it was again said that to bring girls at an equal level of boys there must be additional facilities for female students at all levels of education including higher education. Thus the issue of equity was hardly introduced till the 80s but with ambiguity in later policies even (Qutoshi, 2015).

\section{Politics of Reforms in Education}

As a result of reforms in higher education, however, NEP 2009 came with the term 'equity' focused support through the provision of grants/scholarship/ assistantships to graduates within the country and abroad since the inception of Higher Education Commission (HEC) in Pakistan. Equity centered support means to give all possible support to candidates for their access to higher education (Ramsay, 1999) but little relaxed rules for some geographically underdeveloped areas didn't fulfill their needs of access to higher education. Fair discussion on such issues inferred that even current education policies have limited scope and are silent towards unprivileged masses.

Reflections on the results of reforms moments since 1947 revealed that the equity-centered policies and practices have not been practiced in Pakistan. Moreover, the impact of these reforms on Pakistani society especially the marginalized one(s) has been negative rather than improving the state of higher education. On one hand, existing policies do not clearly define equity focus measures for the economically marginalized and ethnically/geographically disadvantaged segments of the society (Ramsay, 1999) and on the other hand, such reforms have been encouraging parallel education systems in the country to facilitate the elite class (Ashraf \& Kopweh, n.d.; Khalique, 2007).

Pakistan has a diverse society in terms of language, ethnic and socio cultural background, political, religious, and geographical aspect. On one hand, Pakistani society opted for either general system of Urdu medium of education including religious education (e.g., Madrasah education for the lowest economic class) or 'so-called English medium system of educational institutions' termed as Low Fee English Medium Schools mushrooming mostly in urban areas (Muzaffar, 2010). On the other hand, the ruling class and/or topocracy who in the history of this country every time remained a highly influential segment of the Pakistani society enjoys the quality of basic life opportunities both within the country and abroad. Then the question is 'how so-called equity policies can address diverse groups of people living in this country?'

Thus the current policies practiced in Pakistan are highly influenced by the politics of topocracy, the new colonial masters and are absolutely none friendly towards 'the Rest - the poor public, the masses. Moreover, the focus of reforms in education has been donor driven and making education as a business good rather than a public good. As "education is both a public and private good" (Muzaffar, 2010, p12) it is rather than focusing on quality of education for all it is encouraging and facilitating the ones closer to the center (the ruling ones) rather than periphery (the general masses).

However, a change in the political mindset, it is hoped that putting conscious efforts might open new windows to look at and understand this class from the historical viewpoint. Reflecting critically on the state of access to and quality of education in general and higher education in particular with reference to existing policies and practices through equity lens and their impact on masses especially graduates living in underdeveloped areas like GB, Chitral, Baluchistan, and border areas, to name but a few, open our eyes to understand why inequity policies exist in Pakistan. And to what extent this topocracy is adding its input unconsciously in addressing the issues of inequity and/or complicating the issue more severely.

\section{Implications of the Politics of So-Called Equity Policies for Higher Education}

A long history of poor policies and practices created a space for policymakers to bring reforms in education in the country. However, such reforms have been under the influence of a political-donordriven rather public demand-based agenda to improve access to higher education for lower 
socioeconomic class students especially living in underdeveloped areas (Frenette, 2007; Knight, 2009). Thus, the politics of some so-called equity policies seem to make education as a business good by introducing self-finance education programs- means a 'quota for richer' rather than making it a public good (Sustainable Development Policy Institute [SDPI], 1995, P.8).

In the context of Pakistan, the term equity, in the above-mentioned article (SDPI, 1995), has been discussed to some extent, which has been deliberately complicated to understand its true essence. For instance, equity means "the quality of being fair and impartial" to others (Ashraf \& Kopweh, n.d, p. 10). What does it mean to be fair and impartial? So, it did not say to provide additional and unconditional support to the disadvantaged members of the society through provision of extra resources and putting more efforts in order to enable them to come closer to the center from the peripheries (Qutoshi, 2015).

The concept of equity means to be more generous, loving, scaffolding and caring towards the weak/disadvantaged, marginalized and powerless in order to empower them with extra measures to uplift the poverty-stricken, legally marginalized and naturally disadvantaged segments of society. Whereas the current policies do not highlight anything like this and the practices show no such kind of support that is given on the grounds of such kind of concepts to the powerless in order to empower them.

It is inferred that the concept of equity defined in the context of Pakistan needs to understand through conscious critical reflections on policies and practices related to this term that can open a window to see how much-disadvantaged classes are suffering due to ambiguous and vague definitions of terms like equity in policies and practices (Qutoshi, 2015). Whereas, our topocracy has only access to quality education either in the country or abroad rest face unnecessary and unfriendly rigid criteria to access higher education for such segments of the societies. Pakistan could not support vision 2030 which emphasizes huge investment in higher education (Rehman \& Sewani, n.d.). However, the existing policy on higher education in line with the objectives of the HEC does not show any focused opportunity for higher education like provision of special scholarships /grants/loans and support programs.

\section{Politics of So-called Equity Policies}

The politics of scholarship schemes introduced based on area/place specific to show an equity-policy provision towards disadvantaged groups like less developed areas of Baluchistan and GB do not cater the needs of deserving disadvantaged masses struggling for higher education. For example, if an individual from marginalized areas receives admission in a higher education institution somewhere abroad there are no flexible rules for such graduates to receive grants from HEC except to follow the equality-based criteria made for all. As a result of such kind of so-called equity policies and practices of HEC, hardly few graduates from disadvantaged areas can get access to higher education within the country and abroad.

However, the outcome of existing policies helped the upper economic class to a great extent that can easily fulfill the given general criteria and get access to quality higher education both inside and abroad. Whereas, few of the lower economic class and a few graduates from underdeveloped areas hardly access such opportunities. Whatever the case may be returning to the home station after completing higher studies only two categories of the awardees reluctantly rejoin home institution in Pakistan:

1) In-service permanent employees (in most cases public sector employees) due to tough agreements with their home institutions rejoin their service but few of them still found hunting other opportunities abroad even resigning from their permanent jobs;

2) Majority of Pre-service fresh graduates prefer to stay abroad and do not come back to Pakistan.

Thus, such policies can pave the way to brain drain and keep the areas underdeveloped forever.

This seems another kind of hidden policy to rule over the marginalized areas- another form of colonization by policymakers. Hoodbhoy rightly criticized the politics of policies for higher education in Pakistan. He argued that 'HEC actually made some problems worse' for example, failure to form equity policies towards highly marginalized ones (2010, p.1).

\section{The Limitations of Policy Provision on Equity}

There is no doubt that the policies are mostly equality-based not equity-based because of the existing criteria that there is no provision for equity-centered scholarships schemes except equality based on fixed and rigid criteria (HEC, 2013). Until and unless HEC as an umbrella institution for higher education does not reflect on such rigid policies, ineffective practices and its outcomes, the disparities among 'haves and have-nots' will further widen in future. 
It seems that some elements with separatist agenda may take advantage of such injustices and can harm the country. So, the residents of Gilgit-Baltistan (GBians), as patriots would not like to be part of such disparity games played at either ends but highly demand for equity-based policy provisions to facilitate the future generation of the region- the graduates of this land in order to ensure maximum access to quality higher education opportunities.

Therefore, it is necessary for these policy-making bodies to revisit existing policies and bring context specific reforms by addressing the real needs of minorities, disadvantaged groups and other marginalized segments of the society in accessing quality higher education opportunities. For instance, one can reflect on some of the rigid policies which do not allow poor educational and economic background graduates belong to undeveloped areas in Pakistan to avail scholarship like 1) Merit-based scholarship - students studying in world top 200 ranking universities; 2) Scholarships for HEC recognized universities of Pakistan; and 3) Policy limitations- age-specific; subject-specific; and university-specific - No equity but strict criteria that is an obstacle.

Based on the existing strict policies and practices on the ground most of the deserving candidates cannot avail higher education opportunities within the country and/ or abroad. If the policies will be made equity-friendly and need-based maximum number of graduates even the existing in-service faculty members especially in public sectors universities can get more chances to access higher education either within the country or abroad. It would be better to revise the existing rigid policies creating enough space for ethnic identities, differently abled persons and disadvantaged classes of the society to enable them to avail higher education opportunities. Secondly, by reflecting on such issues, HEC would assist continuous professional development and exposure of the faculty and students belong to underdeveloped areas: 1) Develop broad-based exchange programs - need equity first, merit cum equality, not the existing one; 2 ) Provision of loans and other financial assistance programs to encourage disadvantaged individuals in public and private sectors; and 3) Need new policies which prioritize faculty development in new universities and more chances for professional development?

\section{CONCLUSION}

In the line of critical discourse in this article, the questions arise here are: Why the government of Pakistan could not come up with an equity-based policy to facilitate a marginalized group of people in the country and in so doing whose interest is being well served? Who is responsible for not introducing policies that could have helped citizens in the country particularly living in the periphery from the center such as GB and Chitral? To address these questions, policy-making processes need to be understood because the intentions of policymakers are guided by new post-colonial masters of Pakistan for devising policies benefitting only close to the center. A historical perspective reveals that the demise of Western Colonization gave birth to a new form of colonization - Topocracy in post-colonial states including Pakistan. Having inherited a style of governance, the topocrates till this time did not seem different from the Western Colonizers. As a result, masses have been suffering since the inception of Pakistan due to high influence of this class in almost all forms of life that define policies for self/others (others of similarity the upper socio-economic classes and others of different groups).

The topocracy friendly policies in the country created many disparities which do not seem to facilitate masses instead of reform moments in the country. In the light of prevailing issues related to the policy guidelines for higher education in the country, the provision of scholarships, grants, assistance programs, and loan schemes do not reflect equity with reference to marginalized areas. Thus, the existing policies in higher education seemed to be unfriendly, limited and tough towards graduates from disadvantaged areas especially GB who are willing to access to higher education within or out of the country. For example, scholars from underdeveloped regions who are studying in universities abroad and getting no assistance from HEC due to tough criteria is an example of disparity. It is highly desirable to address such problems through inclusiveness towards such scholars in their struggle for better life chances both within and abroad.

\section{REFERENCES}

Ali, S. (2017). The sphere of authority: Governing education policy in Pakistan amidst global pressures. Globalisation, Societies and Education, 15(2), 217-237.

Ali, S. (2013). Pakistan: Target revision in education policy. Education in West Central Asia, 30, 163. 
Ali, S. (2012). Education policy borrowing in Pakistan: Public-private partnerships. Education in the broader Middle East: Borrowing a baroque arsenal, 23-40.

Ali, S. (2009). Governing education policy in a globalising world: the sphere of authority of the Pakistani State.

Ali, S. (2006). Why does policy fail? Understanding the problems of policy implementation in Pakistan-a neuro-cognitive perspective. International Studies in Educational administration, 34(1).

Ali, S. (2005). The influence of globalisation on the national education policies of developing countries. Journal of Educational Research, 8(1), 14.

Ali, S., \& Tahir, M. S. (2009). Reforming education in Pakistan-tracing global links. Journal of Research and Reflections in Education, 3(15), 1.

Ashraf, M., \& Kopweh, P. (n.d.). Globalization and education policy of Pakistan: the challenges of access and equity in education. Accessed from: http://www.periglobal.org/sites/periglobal.org/files/9.Globalisation\&Education_Policy_Pakistan $\% 28$ Ashraf\%29.pdf

Aziz, M., Bloom, D. E., Humair, S., Jimenez, E., Rosenberg, L., \&Sathar, Z. (2014). Education System Reform in Pakistan: Why, When, and How? IZA Policy Paper No. 76. Retrieved from: http://ftp.iza.org/pp76.pdf

Brookfield, S. (1995). Becoming a critically reflective teacher. San Francisco, CA: Jossey-Bass.

Carspecken, P. F. (1996). Critical ethnography in educational research: a theoretical and practical guide. New York: Routledge.

Fairclough, N. (2013). Critical Discourse Analysis: The critical study of language (2 ${ }^{\text {nd }}$ Ed.). New York: Routledge.

Frenette, M. (2007). Why Are Youth from Lower-income Families Less Likely to Attend University? Evidence from Academic Abilities, Parental Influences, and Financial Constraints. Analytical Studies Branch Research Paper Series, Statistics Canada.

Habermas, J. (2015). Knowledge and human interests. John Wiley \& Sons.

HEC. (2013). International research support initiative program. Retrieved from: http://www.hec.gov.pk/InsideHEC/Divisions/HRD/Scholarships/ForeignScholarships/ISSIP/Page s/eligibilityCriteria02.aspx.

Hoodbhoy, P. A. (n.d). Education Reform in Pakistan -Challenges and Prospects. Retrieved from: http://www.pc.gov.pk/vision2030/approach\%20paper/t3/theme\%203-Pervaiz\%20Hudbouy-1.pdf

Hoodbhoy, P. A. (2010). Reckoning time for the HEC. Retrieved from: http://eacpe.org/content/uploads/2014/02/Reckoning-time-for-the-HEC.pdf

Khan, S. M. (2011). Comparative Analysis of Teacher Education Programmes in Pakistan and UK. A doctoral thesis submitted to the Faculty of Arts, Social Sciences, \& Education Sarhad University of Science and Information Technology Peshawar, Pakistan.

Khushik, F., \& Diemer, A. (2018). Critical analysis of education policies in Pakistan: A sustainable development perspective. Social Science Learning Education Journal, 3(09), 01-16.

Knight, J. (Ed.). (2009). Financing Access and Equity in Higher Education (Edt.). Ontario Institute for Studies in the Education University of Toronto, Canada: Sense Publishers.

Malik, S., \& Courtney, K. (2011). Higher education and women's empowerment in Pakistan, Gender and Education, 23(1), 29-45.

Mehmood, K. (2016). Study Report - Overall assessment of the higher education sector. Retrieved from http://hec.gov.pk/english/universities/projects/TESP/Documents/FRAssessment\%20HE\%20Sector.pdf

Morley, L. (1997). Change and Equity in Higher Education. British Journal of Sociology of Education, Vol. 18, No. 2 (1997), pp. 231-242.

Muzaffar, I. (2010). Education in Pakistan: The nickel and dime route to ruin. Lahore: Campaign for Quality Education Secretariat.

Qutoshi, S. B. (2015). Financing of Higher Education in Pakistan: Initiatives, challenges, and outcomes. Hope Journal of Research, 2(4), 2313-8122. 
Ramsay, E. (1999). The National Framework for Australian Higher Education Equity: Its Origins, Evolution and Current Status. Higher Education Quarterly, 0951-5224, Volume 53, No. 2, pp 173-189.

Rehman, M. H., \& Sewani, S. M. S. (n.d.) Critical Analysis of the Educational Policies of Pakistan.

Retrieved from

http://www.qurtuba.edu.pk/thedialogue/The\%20Dialogue/8_3/Dialogue_July_September2013_24 7-260.pdf

Sustainable Development Policy Institute (1995). Equity in Public Sector University Admissions Policy in Pakistan. Sustainable Development Policy Institute (SDPI). Policy Paper Series \# 23. Islamabad, Pakistan.

The government of Pakistan (1972). The Education Policy 1972-80, Ministry of Education, Islamabad, Pakistan.

The government of Pakistan (1979). National Education Policy 1979, Ministry of Education, Islamabad, Pakistan. 